\title{
You May Clap But We are Soon Forgotten
}

\author{
Aayushi Pandya MBBS \\ Academic Foundation Y2, Brighton, UK
}

\begin{tabular}{ll} 
Article Information & \\
\hline Submitted & 18 Jun 2020 \\
Online Sushruta.net & 18 Jun 2020 \\
Published & 18 Jul 2020 \\
Curated by & Triya Chakravorty
\end{tabular}

You may clap, but we are forgotten.

Health Secretary, Matt Hancock, has stated that people from Black, Asian or Minority Ethnic (BAME) backgrounds are "disproportionately" dying with coronavirus [1]. The National Health Service (NHS), an organization of extremely diverse staff members, echoes this claim [2, 3]. Where 21\% NHS staff are BAME, 63\% healthcare workers who have died were BAME; where $44 \%$ doctors are BAME, 95\% doctors who have died were BAME [4].

Due to emerging evidence, NHS England advised trusts to perform updated risk assessments on BAME staff [5], but nearly 40\% BAME doctors had not received these when Public Health England's report emerged last week [6]. Not only are we left with little to alleviate our concerns, but there are simply no solutions once assessed [7], rendering this a purely tick-box exercise.

My personal experience of this risk assessment was just this, through no fault of the individual, department or trust.

1. Do you feel more at risk given the evidence about BAME individuals being more at risk for Covid-19? I was not sure how to answer a question where the answer was already present. 2. Has emerging evidence about BAME risk increased your anxiety or led to other mental health concerns? Surely the question is flawed in itself? Like many of my colleagues, I said no; we're all just as anxious. A solid, politically correct, 'we're all in it together', response.

3. Do you feel more likely to do things you would otherwise be uncomfortable in doing because of your BAME background? Rephrased - are you less likely to say no to doing things at work? Here, I was quick to claim that if this was the case, it would be because of my 'personality'. Thus, I disregarded the cultural elements of our personalities and that as immigrants or children of immigrants, we will always hesitate to say no and avoid doing so. This quality translates to all aspects of life, this nature to please at the expense of yourself.

Ultimately, coronavirus thrive on inequalities [8], which include: socio-economic backgrounds, crowded living, increased genetic predisposition to chronic health conditions [1, 9], and subconsciously chosen 'key worker' professions in the BAME community, likely based on immigration rules that on UK arrival, you offer a 'service'. But let us examine the greatest inequality, where BAME individuals are so conditioned to put themselves second just to be seen as 'the same', in a society which perpetuates this.

Of course, we cannot shield 40\% doctors, $20 \%$ nurses [10] and all other BAME key workers. However, recommendations could be offered? Or failing that, surely BAME workers should have had a risk assessment by now, carried out by a fellow BAME individual? It is criminal to rob so many colleagues of a forum to express their thoughts and fears, with someone in a similar position. When we make up so much of the key worker body, NHS and otherwise, please do not forget us. We never wanted your claps; we just wanted equality.

Conflict of Interest Declaration None 
Aayush Pandya is an academic foundation year two doctor in Brighton. She graduated from Kings College London in 2018 with the School of Medicine Silver medal. She is passionate about tackling inequalities, volunteers for Anthony Nolan and is pursuing her interests in Global Women's Health through a Masters in London.

References

[1] Butcher, B. \& Massey, J. Why are more people from BAME backgrounds dying from coronavirus? BBC News. 2020. Available from: https://www.bbc.co.uk/news/uk-52219070 [Accessed 10th June 2020]

[2] Cook, T., Kursumovic, E. and Lennane, S. Exclusive: deaths of NHS staff from covid-19 analysed. HSJ. 2020. Available from: https://www.hsj.co.uk/exclusive-deaths-of-nhs-staff-fromcovid-19-analysed/7027471.article [Accessed 10th June 2020] [3] Kline, R. NHS Covid 19 and health care worker deaths: questions that need asking. Race Equality Foundation. 2020. Available from: https://raceequalityfoundation.org.uk/healthcare/nhs-covid-19-and-health-care-worker-deaths-questionsthat-need-asking/ [Accessed 10th June 2020]

[4] British Medical Association. COVID-19: the risk to BAME doctors. BMA. 2020. Available from: https://www.bma.org.uk/advice-and-support/covid-19/yourhealth/covid-19-the-risk-to-bame-doctors [Accessed 10th June 2020]

[5] Bostock, N. All BAME staff must be risk-assessed before seeing patients face-to-face, warns NHS England. Available from: https://www.gponline.com/bame-staff-risk-assessed-seeingpatients-face-to-face-warns-nhs-england/article/1685791

[Accessed 10th June 2020]

[6] Hasan, R. Nearly $40 \%$ of BAME doctors still not given coronavirus risk assessments recommended to prevent deaths. ITV News. 2020. Available from: https://www.itv.com/news/2020-06-06/nearly-40-of-bamedoctors-still-not-given-coronavirus-risk-assessmentsrecommended-to-prevent-deaths/ [Accessed 10th June 2020] [7] Khunti, K \& Pareek, M. Covid-19 in ethnic minority groups: where do we go following PHE's report? BMJ Opinion. 2020. Available from: https://blogs.bmj.com/bmj/2020/06/08/covid-19-in-ethnicminority-groups-where-do-we-go-following-phes-report/ [Accessed 10th June 2020]

[8] Morgan, E. 'Coronavirus thrives on inequalities': BAME people up to twice as likely to die from Covid-19. ITV News. 2020. Available from: https://www.itv.com/news/2020-06$02 /$ coronavirus-thrives-on-inequalities-and-being-bame-ismajor-risk-factor-report-suggests/ [Accessed 10th June 2020]

[9] British Heart Foundation. Why are so many people of ethnic minority background dying from coronavirus - and what does it have to do with heart disease? BHF. 2020. Available from: https://www.bhf.org.uk/informationsupport/heart-mattersmagazine/news/behind-the-

headlines/coronavirus/coronavirus-and-bame-patients [Accessed 10th June 2020]

[10] NHS Digital. NHS Workforce Statistics - March 2019 (Including supplementary analysis on pay by ethnicity). NHS workforce statistics. Available from: https://www.ethnicityfacts-figures.service.gov.uk/workforce-andbusiness/workforce-diversity/nhs-workforce/latest\#byethnicity [Accessed 10th June 2020] 